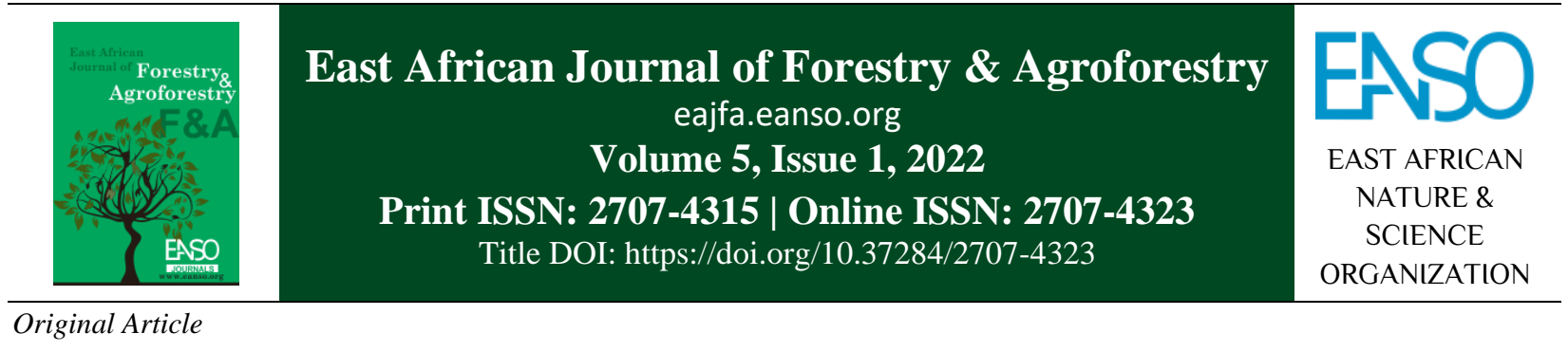

\title{
Adoption and Implementation of Devolved Farm Forestry Extension Services from Kenya Forest Service to County Governments: Socio- Economic Wellbeing of Rural Communities and Experiences from Homabay County, Kenya.
}

\author{
Akoth Lucy Ojijo ${ }^{1 *}$, Dr. Sirmah Peter Kipkosgei, PhD ${ }^{1}$, \& Dr. Matonyei Thomas Kibiwot, PhD \\ ${ }^{1}$ University of Kabianga, P. O. Box 2030-20200, Kericho, Kenya. \\ * Author for Correspondence ORCID: https://orcid.org/0000-0002-6566-3265; email: Lucyakoth01@ gmail.com.
}

Article DOI: https://doi.org/10.37284/eajfa.5.1.539

\section{Date Published: ABSTRACT}

31 January 2022 In Kenya, all forestry functions were National Government affairs until 2013 when farm forestry extension was devolved to the 47 Counties, Homabay

Keywords: County being one of them. However, the adoption and extent of implementation of the devolved farm forestry extension services are little

Farm Forestry, known and its impact on rural livelihoods has not been effectively Devolution, established as well as the implementation of the Transition Implementation Homabay County, Plan by the County Government of Homabay is not evident. Structured Extension, questionnaires were administered purposively to 399 respondents spread in Kenya. eight Sub-Counties of Homabay to gather data on the extent of implementation of the devolved farm forestry extension services, to evaluate socio-economic effects of farm forestry extension services to rural communities and the extent of adoption of devolved farm forestry extension services. Results indicate the extent of adoption of farm forestry extension services is low with the farmers expressing that as much as it's a devolved function, it is not an active process within the rural communities (82\%). The key socio-economic factors that affect the adoption and implementation of devolved farm forestry are; farmers level of income for purchase of tree seeds (61\%), market availability for tree seedlings (44\%), land sizes and tenure systems (68\%). The extent of implementation was influenced by County Government budget allocation and prioritization (67\%), availability of qualified personnel $(81 \%)$, government policies on interactions between the two levels of governments $(49 \%)$ and obligation to the Transition Implementation Plan (89\%). The results suggest that County Government needs to prioritize budget allocation and have adequate personnel as means

9 | This work is licensed under a Creative Commons Attribution 4.0 International License. 
to adequately implement the devolved functions and also to implement the Transition Implementation Plan as laid down by the Kenya Forest Service.

\begin{abstract}
APA CITATION
Ojijo, A. L., Kipkosgei, S. P., Kibiwot, M. T. (2022). Adoption and Implementation of Devolved Farm Forestry Extension Services from Kenya Forest Service to County Governments: Socio-Economic Wellbeing of Rural Communities and Experiences from Homabay County, Kenya East African Journal of Forestry and Agroforestry, 5(1), 9-21. https://doi.org/10.37284/eajfa.5.1.539
\end{abstract}

\title{
CHICAGO CITATION
}

Ojijo, Akoth Lucy., Sirmah Peter Kipkosgei, Matonyei Thomas Kibiwot. 2022. “Adoption and Implementation of Devolved Farm Forestry Extension Services from Kenya Forest Service to County Governments: Socio-Economic Wellbeing of Rural Communities and Experiences from Homabay County, Kenya”. East African Journal of Forestry and Agroforestry 5 (1), 9-21. https://doi.org/10.37284/eajfa.5.1.539.

\section{HARVARD CITATION}

Ojijo, A. L., Kipkosgei, S. P., Kibiwot, M. T. (2022), “Adoption and Implementation of Devolved Farm Forestry Extension Services from Kenya Forest Service to County Governments: Socio-Economic Wellbeing of Rural Communities and Experiences from Homabay County, Kenya", East African Journal of Forestry and Agroforestry, 5(1), pp. 9-21. doi: 10.37284/eajfa.5.1.539.

\section{IEEE CITATION}

A. L. Ojijo, S. P. Kipkosgei, M. T. Kibiwot, “Adoption and Implementation of Devolved Farm Forestry Extension Services from Kenya Forest Service to County Governments: Socio-Economic Wellbeing of Rural Communities and Experiences from Homabay County, Kenya”, EAJFA, vol. 5, no. 1, pp. 9-21, Jan. 2022.

\section{MLA CITATION}

Ojijo, Akoth Lucy., Sirmah Peter Kipkosgei, Matonyei Thomas Kibiwot. "Adoption and Implementation of Devolved Farm Forestry Extension Services from Kenya Forest Service to County Governments: Socio-Economic Wellbeing of Rural Communities and Experiences from Homabay County, Kenya". East African Journal of Forestry and Agroforestry, Vol. 5, no. 1, Jan. 2022, pp. 9-21, doi:10.37284/eajfa.5.1.539.

\section{INTRODUCTION}

The devolution of forest management regime has gained currency in developing countries in recent years and is being viewed as a means of enhancing economic efficiency, public accountability, community and individual empowerment and allocating efficiency in the forest sub-sector (Agrawal et al., 2008). Two major pathways to the governance of forest devolution are represented among Asian countries where there was increased growth of publicly owned forests reserved for use by communities and indigenous people. The Philippines for instance focused on devolution approaches majoring on delegating rights and responsibilities over state forestlands to communities and other types of groups (Dahal et al., 2008). Nepal is seen to have most success in devolving a substantial portion of forest rights to the community by devolving nearly one-fourth of the Nepal forest to 14,000 community forest user groups. The emergence of extensive and highly organized governance systems has improved the success of Nepal forest governance and devolution efforts (Dahal, 2008; Teresai, 2014). Forestry devolution goals such as environmental, protection and rural livelihood improvement should be adequately addressed to create awareness of the instinct value of forests and lack of farm forestry knowledge among local farmers (Dang et al., 2019).

Other African countries like Sudan and Uganda have also taken initiatives towards the devolution of forestry rights. In Uganda, nationwide extension began in colonial times, and forestry extension used to be done alongside agricultural extension services with extension agents who, although they had a general knowledge of agricultural systems, were not trained to provide specific forestry services (Semana, 2004; Teresia, 2014.). In Sudan, for centuries, rural people developed great knowledge and systems of organization and management of local affairs in general and natural resources in particular as a result of devolution (Abdalla, 2011). Through such, tribal leaders assumed functions of tax collection, enforcing law and order 
implementing natural resources laws set by the government based on tribal traditions and this ensured smooth transition of devolved forestry functions (Abdalla, 2011).

Forestry extension as a discipline began as a process of knowledge transfer, from the know-all researchers to the know-nothing farmers, which entailed moving away from the costly state-centred control towards approaches with local people playing a role in natural resources management (Oloo, 2014). Later forestry extension became regarded as a process of integrating indigenous and derived knowledge, attitudes and skills to determine what is needed, how it can be done, what local resources can be mobilized and what additional assistance is available and can be necessary to effectively overcome particular obstacles (Mwangi \& Kariuki, 2015). Several farm forestry extension systems have been established in order to realize national food security goals in most countries (Swanson, 2006; Ruifa et al., 2009; Teresia., 2014). However several factors including budgetary constraints, adequate personnel and limited land sizes have forced many governments to reform their public agricultural and forestry extension systems from downsizing due to reduced financial allocations since devolution (Agrawal et al., 2008; Teresia.,2014;).In some countries like Europe, the reforms changed from privatization to public ownership, whereas in most developing countries, for instance in Uganda, they involved decentralization and commercialization of forestry. (Anderson \& Feder, 2004; Rivera \& Alex, 2004; Ruifa et al., 2009; Teresia., 2014).

Traditionally, farm forestry extension in Africa was focused on increasing forest productivity, improving farm yields, training farmers, and technology transfer from the know it all extension service providers to the know nothing farmer. This employed approaches such as Integrated Rural Development Program, farmer training and field visit extension approach, and farmer field schools with an aim of empowering farmers and delivering farm forestry extension services adequately (Teresia; 2014; Abdallas.,2011).Simmilarly,studies have expressed that forestry extension have significant positive effects on increasing farm knowledge, adoption of new farming technologies and improving farm productivity (Davis, 2008:
Okuthe, 2013). Earlier readings take into account that denationalisation of land had resulted in farmers' losing access to public agricultural and forestry extension services (Anderson \& Feder, 2004; Teresia, 2014).

Devolution usually transfers responsibilities of services to counties that elect their own governors, raise their own revenues, and have independent authorities to make their own decisions. Article 6 of the Kenyan 2010 Constitution devolved Kenya into 47 counties and furthermore provides that the national and county governments are distinct and interdependent (GOK, 2011). It is on this basis that the Gazetted supplement Number 116 of August 2014, devolves farm forestry extension service from the Kenya Forestry Service to the County Governments with an aim of bringing services closer to the people in order to ensure peoples participation in improving various service delivery in several sectors, farm forestry inclusive (GOK, 2011). However, as much as functions are devolved, several aspects remains unresolved such as allocation of funds for implementation of TIPS as it solely requires county governments to allocate their own revenue for its implementation, the low rate of human resource seconded to county governments and inadequate farmer involvement in planning of the extension programmes as should be done in every extension system for smooth adoption (Rivera \& Alex, 2004; Teresia, 2014.).

Since devolution in Kenya, delivery of extension services has not been clear due to conflicting policies and stakeholders' interests, nongovernmental organizations, public extension service providers, community-based organizations and farmer associations on their arrangements to adopt the devolved functions and implement it effectively. The devolution of farm forestry extension service is very useful to ensure farmers have adequate extension service delivery however, it requires testing of strategies which should be participatory, location specific, have adequate resource allocation and eventually incorporate local needs of the farmers in their mode of farm forestry extension services. (Davison, 2007; Teresia, 2014)

Devolution of farm forestry expects the County governments to deliver extension services to its farmers and gives them a mandate to toll taxes on 
the services they provide (GOK, 2011). This is as a result of the reduced funding from the National government to Counties on the provision of extension services thus the farmers have to contribute towards the services. The most basic factor for farm forestry extension to work successfully in the new structure include farmer awareness and access to information on the devolved extension framework which will help them understand extension methodologies and what contributions is expected from them and in the meantime making it affordable to the farmer in order to ensure effective farmer participation in the implementation of the introduced farming technologies and thus increases adoption of farm forestry practices and efficiency extension service delivery(Teresia, 2014).

The Kenya Forest Service whose sole mandates over the years have been implementing three core programs, namely: forest conservation and management with a focus on the management of natural forests in public land; forest plantations and enterprise with a focus on the development of industrial forest plantations on public land; and farm and dryland forestry development with a focus on the provision of forest extension services for the development of private forests, agroforestry and technical assistance to tree growers (GOK, 2016(b); KFS 2015). With regard to the implementation of the devolved functions, the bigger responsibility for the County Governments is to implement farm and dryland forestry interventions with technical support by the Kenya Forest Service and in so doing, the Kenya Forest Service has come up with the Transitional Implementation Plan to help the counties carry out and understand the devolved forestry activities (KFS, 2015). These reforms are expected to reconcile conservation and livelihood needs. In particular, forest sector devolution aims at enhancing people's livelihoods, poverty elevation and improvement of forest condition. Sustainable forest management is at a key role in Kenya's social and economic wellbeing as most of the county's economic sectors rely on environment-based resources for their existence (TIPS, 2015).

The study aimed at finding out the extent of adoption, implementation and socio-economic effects of the devolved farm forestry extension services by the County government and rural communities in Homabay County, Kenya. The knowledge generated would be very useful in informing the County Government and other stakeholders interested in understanding the benefits of adoption and implementation of the devolved farm forestry extension services delivery to make informed policies to effectively deliver the devolved farm forestry extension services to the rural communities.

\section{MATERIALS AND METHODS}

\section{Study Site}

Homabay County is located in South Western Kenya along Lake Victoria, where it borders Kisumu and Siaya counties to the North, Kisii and Nyamira counties to the East, Migori County to the South and it covers $4,267.1 \mathrm{Km}^{2}$ of land inclusive of water surface of $1,227 \mathrm{Km}^{2}$. The county comprises eight Sub-Counties namely; Homabay, Suba North, Suba South, Rachuonyo North, Rachuonyo South, Rachuonyo East, Rangwe and Dhiwa. Figure 1 represents Homabay County with its Sub-Counties 
Figure 1: Map of Homabay County with its sub-counties

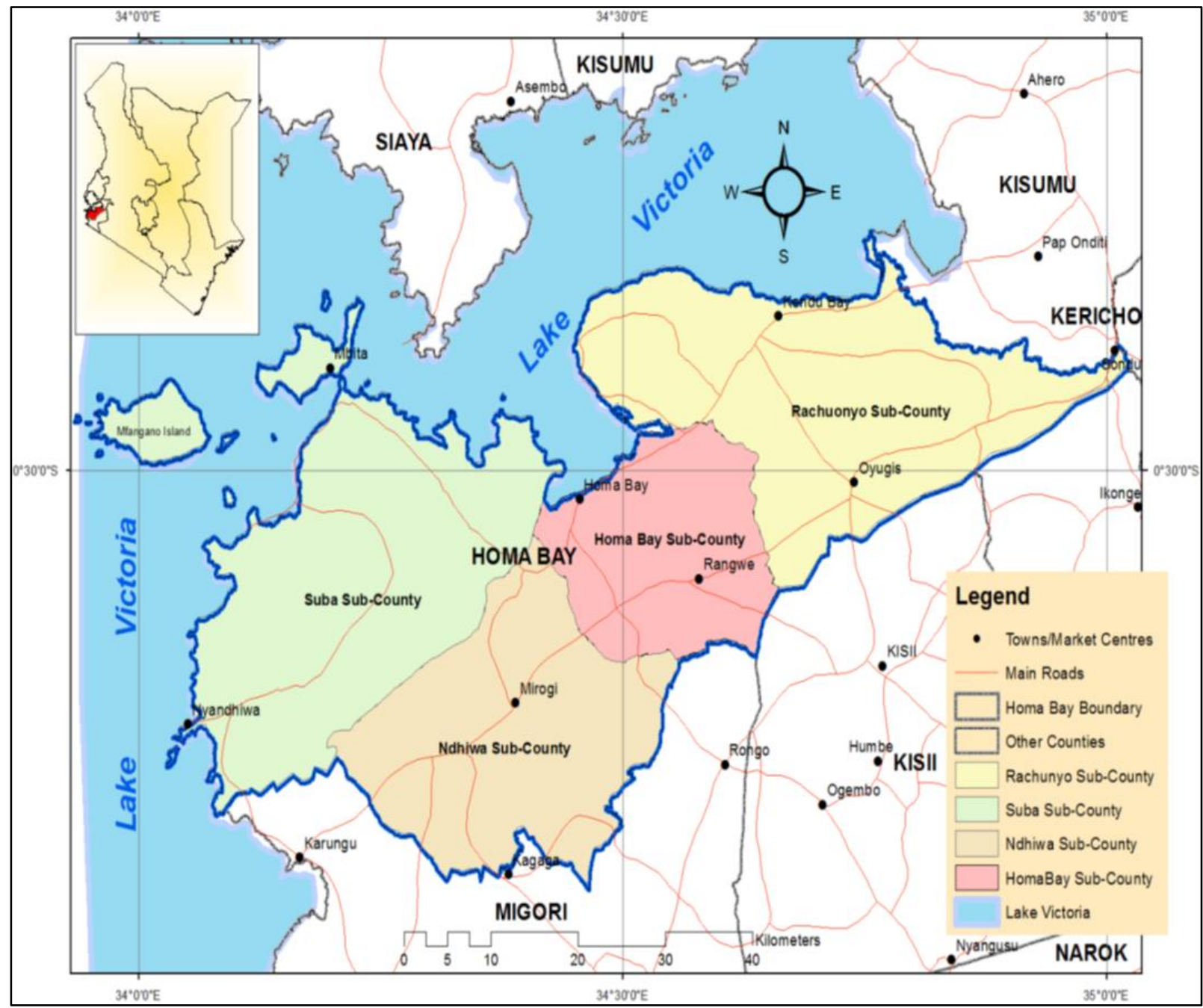

\section{Research Design and Sampling}

The study followed a descriptive research design. The study targeted 262,036 households within Homabay County (KNBS, 2019) and out of this sample size of 399 rural household farmers living in the eight Sub-Counties were purposively selected according to Mugenda and Mugenda (2003). As illustrated in Table 1.

Table 1: Sample population households for the eight Sub-Counties

\begin{tabular}{lll}
\hline Name of Sub County & Household Population $(\mathrm{N})$ & Sample Size $(\mathrm{n})$ \\
\hline Rachuonyo South & 30990 & 47 \\
Rachuonyo North & 41809 & 64 \\
Rachuonyo East & 27319 & 42 \\
Homabay & 29318 & 45 \\
Suba South & 27769 & 42 \\
Suba North & 29766 & 45 \\
Rangwe & 27003 & 41 \\
Dhiwa & 48062 & 73 \\
Total & 262036 & 399 \\
\hline
\end{tabular}

13 This work is licensed under a Creative Commons Attribution 4.0 International License. 


\section{Data Collection}

A structured questionnaire was administered to the 399 sampled members of the eight Sub-Counties.

The questionnaire with closed-ended questions covered the demographic information, socio economic effects and implementation of the devolved farm forestry extension services. Additional information was achieved by interviewing key informants from the Ministry of Environment, Water and Forestry, Kenya Forest Service and Non-Governmental Organizations operating within the research objective. All the data collection tools were pre-tested and verified for effectiveness with a few randomly selected members before use.

\section{RESULTS AND DISCUSSION}

\section{Demographic Information of Respondents in Homabay County}

Table 2 reports the demographic information and socio-economic aspects of households within the eight Sub-Counties.

Table 2: Demographic Distribution of the Respondents in Homabay County

\begin{tabular}{lll}
\hline Item & Description & \% Response \\
\hline & Male & 47 \\
Gender & Female & 53 \\
\hline & Married & 48.9 \\
& Divorced & 20.6 \\
Marital Status & Divorced & 9.3 \\
& Widowed & 14.8 \\
& Separated & 6.5 \\
\hline & $10-20$ & 26.8 \\
Annual income levels (In Ksh thousands) & $20-30$ & 30.1 \\
& $30-40$ & 31.3 \\
Level of Education & $40-50$ & 6.3 \\
& Above 50 & 5.5 \\
\hline & Primary & 7.3 \\
Farm sizes & Secondary & 35.8 \\
& College & 33.3 \\
& First degree & 18.5 \\
Age brackets (years) & Postgraduate & 5 \\
\hline & Under 20 & 4.5 \\
& $21-30$ & 31.6 \\
& $31-40$ & 42.1 \\
& $41-50$ & 14.3 \\
& $>51$ & 7.5 \\
\hline
\end{tabular}

Of the 399 households sampled, females account for $53 \%$ as compared to males at $47 \%$. This indicates that the majority of the respondents were female, the fact that attributed to mostly women spend more time in the household farms compared to men who are engaged in other activities outside the homestead. In most African communities, women make up to between $42 \%-65 \%$ of the agricultural labour force in the world (World Bank, 2014) 
The age brackets of 31-40 years accounted for the highest response at (42\%) which indicates the optimal labour force of respondents within those households carrying out farm forestry and the lowest was the age bracket of less than 20 years at (4\%) which indicates their engagement in other activities with dominant one being academic hence they spend most of the time away from farm forestry. Labour is an essential requirement for optimal productivity in farm practices as most rural communities depend on farming as means of providing food and earnings to their families with adults mostly engaged in forestry practices compared to youths (Sanjay, 2017; Bitange et al., 2021).

The secondary education (35\%) had the highest response rate and the least were postgraduate $(5 \%)$. The level of education is key in determining various aspects such as awareness of devolution and farm forestry awareness provisions by the National and County Governments. The level of education showed that those respondents with higher education like postgraduate increases chances of farm forestry technologies and policies implementation by designing favourable policies on the same as this also contributes to concept and roles understanding (Bastakoti \& Davisen, 2015, Bitange et al., 2021).

The income levels of farmers are a key indicator in understanding the livelihoods and welfare of the households (Abdalla, 2011). Thirty-one (31\%) of the respondents derive their income level from the sale of farm trees KSh. 30-40 per annum, as indicated in Table 2 above. While a minority of the respondents $(5 \%)$ had their income levels over $50 \mathrm{ksh}$ thousand annually. In most populations, higher income in family households is equated to ease of adoption of new farm technologies as well as expand their farm sizes through the acquisition of other lands.

On the marital status of the respondents, $48 \%$ were married, $20 \%$ single, and $9 \%$ divorced, while $6 \%$ and $14 \%$ were separated and widowed, respectively. The community perception of farm forestry is majorly vested in married respondents as compared to those who are single. The majority of households had their farm sizes ranging between 3-5 acres (34\%) and the smaller population has above 7 acres of land (4\%). Land is a key factor Land in Homabay is mostly used for residential and agricultural activities (County Government of Homabay, 2018).

\section{Adoption of Devolved Farm Forestry Extension Services}

Adoption of the devolved farm forestry extension services is essential for the adequate improvement of tree cover in the county. The study investigated that to what extent does $\mathrm{A}=$ farm forestry extension service devolution awareness; $\mathrm{B}=$ farm forestry extension service as an active process in the county and community; $\mathrm{C}=$ devolving farm forestry brought services closer to the people; and $\mathrm{D}=$ the community receives various services from County government such as on advisory, technology transfer and many others for effective farm forestry practices in your area influences extent of adoption of the devolved function. Figure 2 reports the levels of farmer awareness to devolved farm forestry extension services, the delivery of the service, services received and its adoption within Homabay County and the community. 
Figure 2: Level of Satisfaction Against \% Response on Adoption of Extension Services

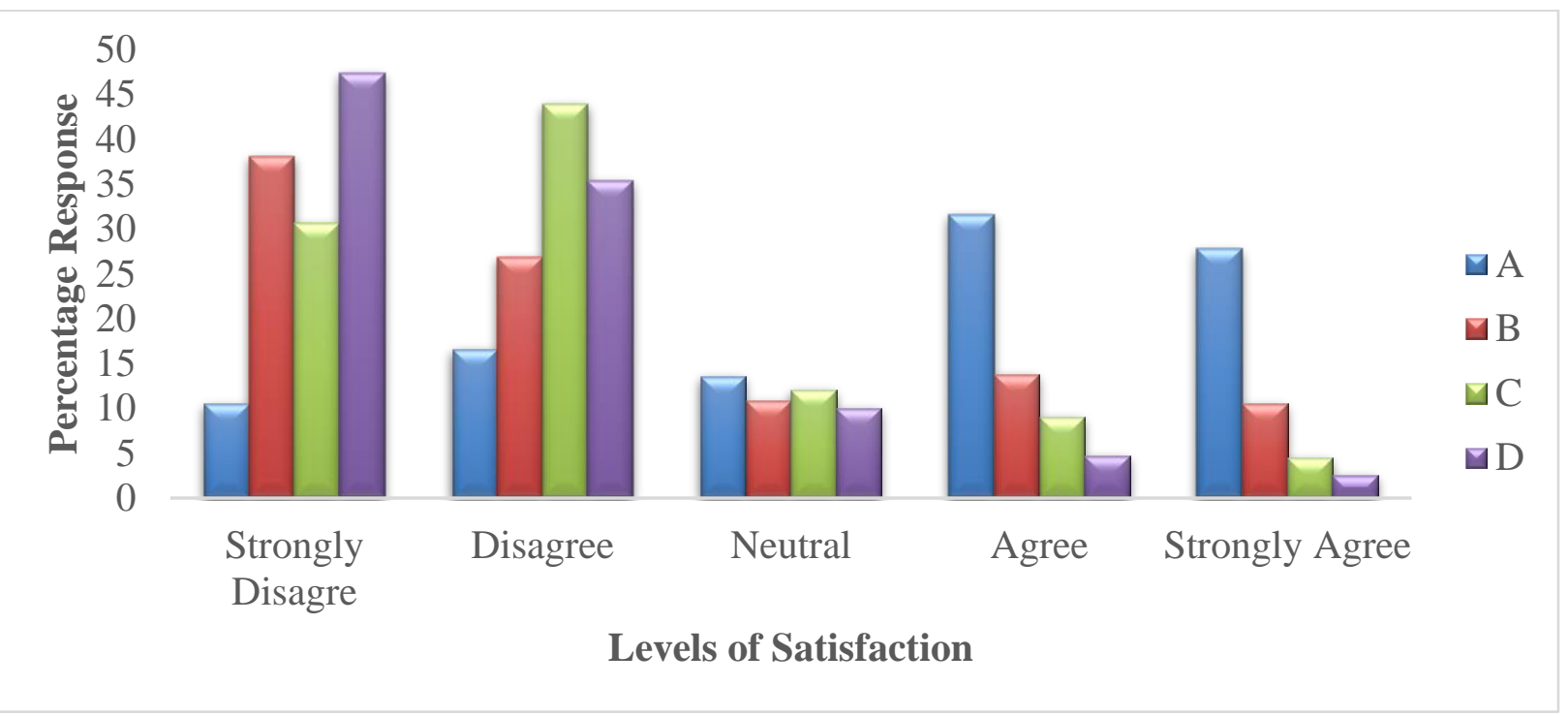

The majority $59 \%$ ) of the respondents acknowledge that indeed farm forestry extension service is a devolved function and is solely vested in county government, while a minority (27\%) disagreed. These findings suggest that the devolved forestry function contributes to improved rural livelihoods in Homabay County. Mbuvi et al. (2018) observed that the devolution of farm forestry aims to improve rural livelihoods and will increase forest cover in Kenya. Sixty-four (64\%) of the respondents disagreed that farm forestry extension service is an active process in their communities due to inadequate awareness, while a minority of the respondents (24\%) agreed to the statement. The study observed that farmers fear incorporating trees on their farms as they would have a negative impact on the soil quality and crop productivity due to farmers limited knowledge of tree species and site matching.

Community involvement in the adoption of devolved farm forestry extension services would mean active participation of community members in decision making and giving them a voice in service delivery, among others (Kiragu, 2002). However, (74\%) of the respondents disagreed that devolving farm forestry services has brought extension services closer to the community, with only $13 \%$ in agreement. Eighty -two (82\%) of the respondents were strongly in disagreement that their community receives various services from the County government on advisory technology transfer, among others as intended by devolving farm forestry to County government, while a minority $(6 \%)$ agreed.

\section{The Socio-Economic Effects of Devolved Farm Forestry Extension Services}

The study sought to understand which socioeconomic factors affect adequate adoption and implementation of the devolved farm forestry extension services. These key factors were established as $\mathrm{H}=$ farm size and land ownership influences decision to plant trees on the farm; I = gender affects planting of trees in the farm; $J=$ tree Seedlings availability and prices economical in your area; $\mathrm{K}=$ availability of ready market for your farm produce.

Figure 3 outlines the various socio-economic factors that affect the adoption of devolved farm forestry extension services. 
Figure 3: Extent of Socio-Economic Influence against (\%) Response of Respondents

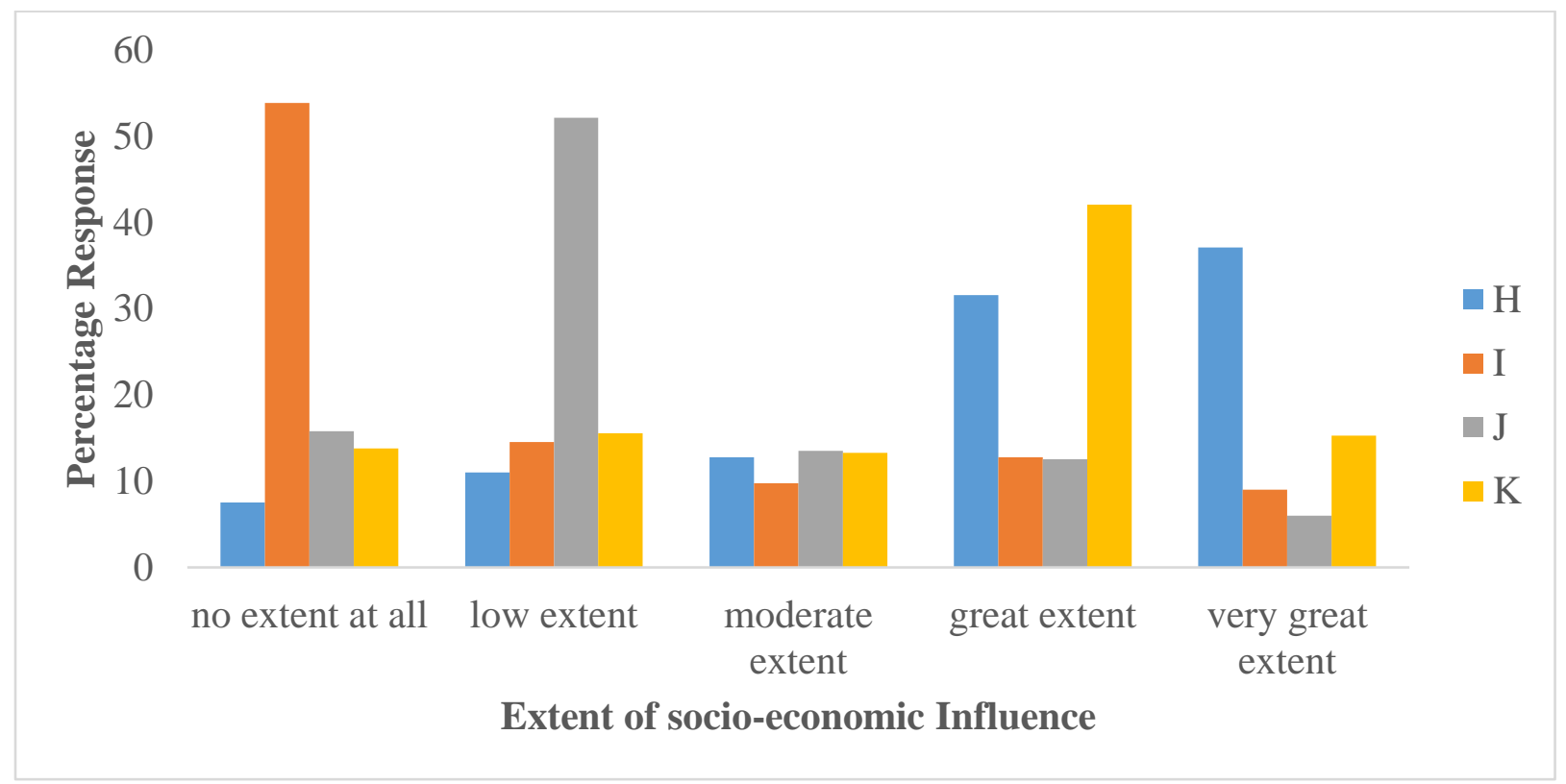

Sixty-eight percent of the respondents (68\%) agree that farm sizes and land ownership influences their decision to plant trees on the farm while $18 \%$ of the respondents expressed that their farm size and tenure rights don't affect their ability to plant trees on the farms. The household landholding is a very important aspect in decision making to plant trees since adequate land enables the household to diversify its farming activities. Household land holdings have contributed to a positive adoption of new technologies and farming practices in other regions (Koppmair et al., 2012). Adoption of new technologies entails subjective risks that smallholder farmers may not be willing to undertake since they have fewer resources to fall back on (Doss, 2006). 52\% of the respondents expressed that to a low extent, tree seedlings are available and prices within their reach. Hence most rural communities just collect locally available seeds and make seedlings that tend to be of low vigour and result in the poor establishment of farm forestry trees and tree nurseries. Tree seedlings available and within local farmer access is a very economical aspect in establishing on-farm tree nurseries (Okuthe, 2010).

Fifty-three percent $(53 \%)$ of respondents expressed to no extent does their gender affect tree planting roles in their farms. Although farm forestry used to be a male profession, women involvement is increasing as they already comprise half of the agricultural farm forestry labour force (Sigdel \& Koirala, 2015). Fifty- seven percent (57\%) of the respondents indicated that greater extent market availability for their farm produce is an essential factor for effective farm forestry adoption. This is particularly relevant in African counties where rural community's dependent on agriculture and natural resources face rising costs of production and marketing (Lasco et al., 2011)

\section{Implementation of the Devolved Farm Forestry Extension Services}

The study investigated the extent of implementation and such factors which influence the successful implementation of the devolved farm forestry extension services within the county. Figure 3 below shows the report on the extent to which the factors $(\mathrm{M}=$ budget allocation; $\mathrm{N}=$ availability of qualified personnel; $\mathrm{O}=$ farm forestry extension service follows up by extension service providers; $\mathrm{P}$ $=$ county obligated to transition implementation plan). 
Figure 4: \% Response on M.N.O.P on Implementation of Devolved Farm Forestry

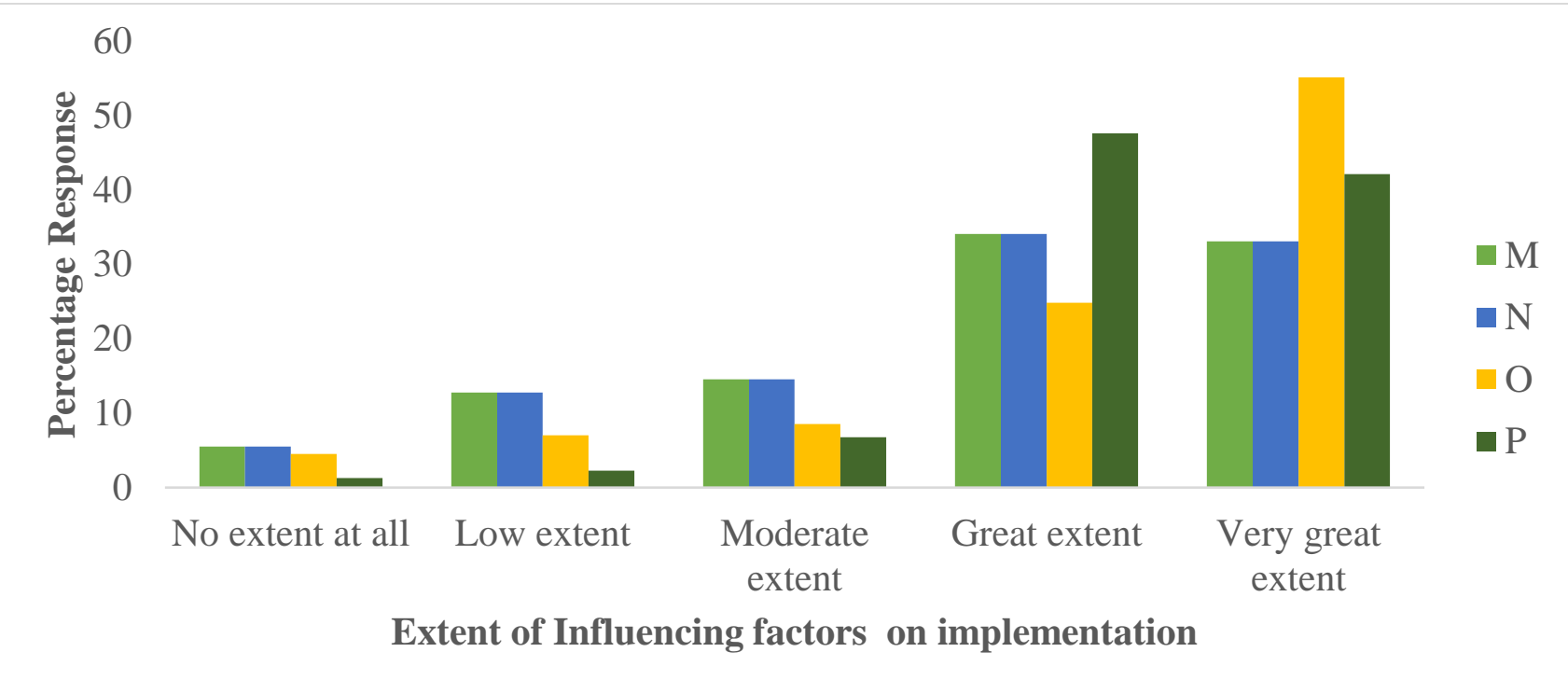

Sixty-seven percent $(67 \%)$ of the respondents agreed the low budget allocated for in County government causes financial constrain, which to a great extent affects the implementation of the devolved farm forestry extension services, while (5\%) expressed that budget allocation had no effect on farm forestry implementation. This arises due to the prioritization of other activities like infrastructure development and less prioritization in allocating sufficient budget towards farm forestry extension services (County Government of Homabay, 2018). Eighty-one percent (81\%) of the respondents expressed that to a very great extent availability of inadequate qualified personnel employed by the County government negatively affect implementation.

Farm forestry activities follow up by extension services providers affects implementation citing low follow-ups at $79 \%$. Eighty-nine percent (89\%) of the respondents agreed that successful implementation of devolved farm forestry extension services is dependent on the County government obligation and effective implementation to the transition implementation plans laid down by the KFS for effective farm forestry administration, while $17 \%$ disagreed.

Further on the implementation, the study analysed the effects of government policies on the interaction between the two levels of government towards adequate farm forestry extension services provision. $\mathrm{Q}=$ Government policies on interaction; $\mathrm{R}=$ interaction between KFS and CG on economic sustainability and resource sharing; $\mathrm{S}=$ reliance on NGO for farm forestry extension services provision; $\mathrm{T}=$ availability of farmer field days for exhibitions and knowledge sharing. Figure 5 below express to what percentage of the extent of interactions that impacts the implementation of the devolved farm forestry extension service delivery to the local communities. 
Figure 5: Extent of Satisfaction of Implementation of Farm Forestry Extension Services Delivery

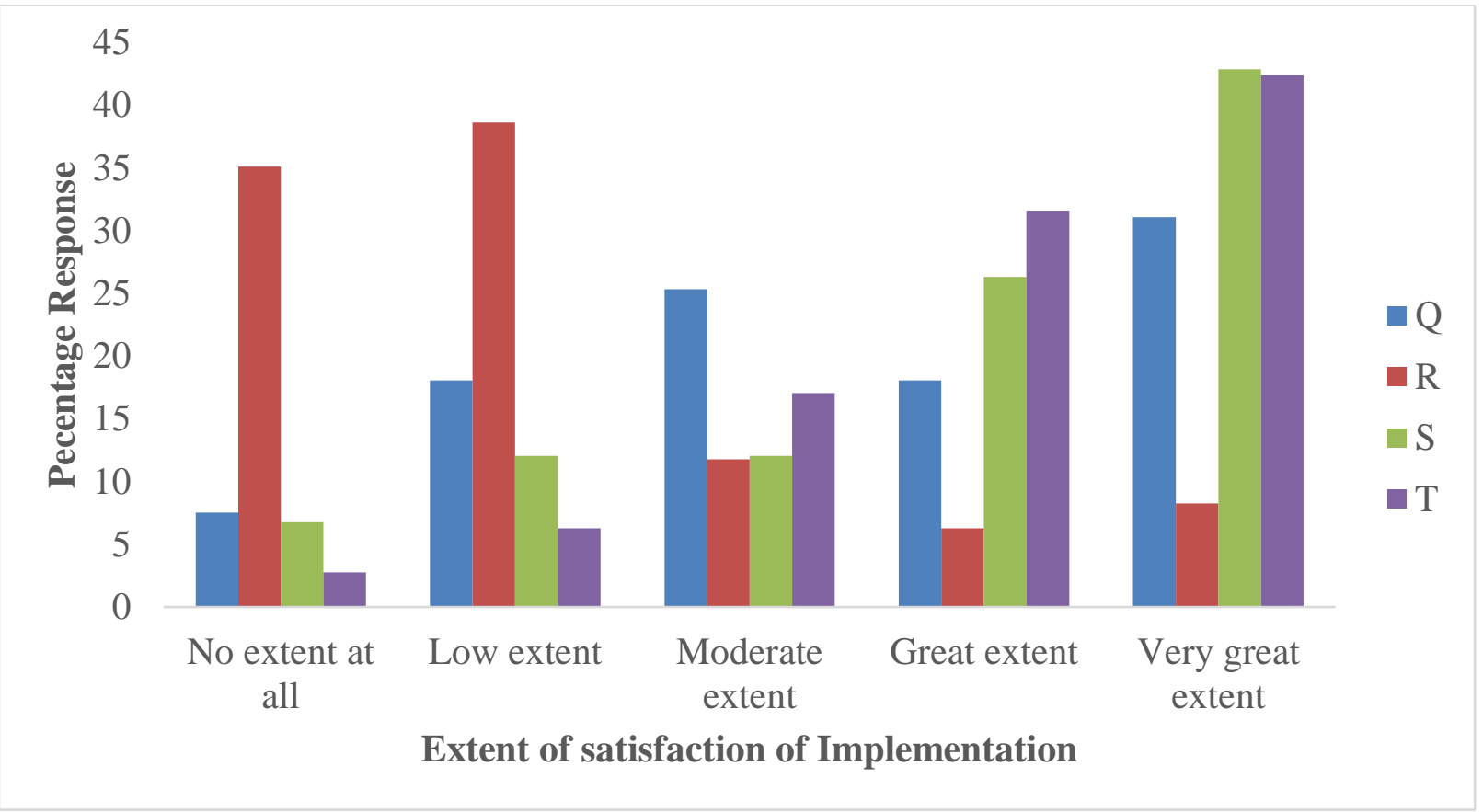

To a very great extent (49\%), government policies on interaction influences implementation with a minority of respondents, $7 \%$ reporting that government policies on the interaction between the two governments have no influence at all on the implementation of the devolved farm forestry extension services. Seventy-three percent (73\%) of the farmers expressed that to no extent the KFS and CG are interacting towards farm forestry extension survives delivery to farmers. These two levels of adequate interaction would enhance adequate implementation of the devolved farm forestry extension as laid in the TIPS (Abdalla, 2011). The Transition Implementation Plan requires that distribution of sectorial functions between the national government (KFS) and the County governments (Homabay County) are set out that for the purposes of programs implementation of devolved forestry functions there be coordination and effective interaction between the KFS and the CG in offering of technical support from KFS to CG and proper extension service towards ensuring farmers are well attended to (TIPS, 2015).

To a very great extent $(68 \%)$, both the County government and the farmers rely on NGOs for effective delivery and implementation of the function with a minority $6 \%$ of the respondents expressing low reliance on other extension service providers. This brings the need for elaborate partnership by both the County government of Homabay and other agricultural service extension providers so as to realize an effective way of sustaining the implementation once the NGOs times out. Availability of field days and farmer exhibitions days to a very greater extent $(73 \%)$ are very impacting on the implementation of farm forestry extension services as farmers get to learn and interact fully with the other farmers and numerous extension service providers and as well they showcase their outputs which gives them good sales.

\section{CONCLUSION AND RECOMMENDATIONS}

The extent of adoption of farm forestry extension service delivery in Homabay County is low with the farmers expressing that as much as it's a devolved function, it is not an active process within the rural communities. The farmers level of income, market availability, land sizes and tenure systems are key socio-economic factors for the adoption of far forestry and finally, the implementation relies heavily on County governments. Budget allocation, prioritization and qualified personnel affect the 
implementation of the devolved farm forestry extension services.

This study suggests that County governments should prioritize budget allocation and increase personnel available to implement the devolved function and as much they should fully Implement Transition Implementation Plan.

\section{ACKNOWLEDGEMENT}

My gratitude to my supervisors, the respondents from Homabay County who took part in the study and to the Devolved ministries, the KFS and NGOs in the study area. My special thanks go to my Father Mr. Paul Ojijo and mother Pheobe Ojijo, the family of Mr Kennedy Ochare and to my daughter, Hillary Meso; thank you for your support and your prayers too.

\section{REFERENCES}

Abdalla, A. I. M. (2011). The Role of Forestry Extension in Raising Standard of Living and Alleviate Poverty. Case of Eloudaya Administrative Unit, Sudan. University of Khartoum.

Agrawal, A., Chhatre, A., \& Hardin, R. (2008). Changing governance of the world's forests. Science, 320(5882), 1460-1462.

Anderson, J. R., \& Feder, G. (2004). Agricultural extension: Good intentions and hard realities. The World Bank Research Observer, 19(1), 41-60.

Bastakoti, R. R., \& Davidsen, C. (2015). Nepal's REDD+ readiness preparation and multistakeholder consultation challenges. Journal of Forest and Livelihood, 13(1), 30-43.

Bitange, J., Sirmah, P., Matonyei, T. (2021). Conservation Activities of Women in Nyangores Forest Station, Mau Conservancy, Kenya. East African Journal of Forestry and Agroforestry, 3(1), 29-39

County Government of Homabay. (2018). First County Integrated Development Plan (CIDP) County Government of Homabay 2018-2022. County Government of Homabay
Dahal, G. R., \& Adhikari, K. P. (2008). Trends and impact of forest tenure reforms in Asia: cases from India, Indonesia, Lao PDR, Nepal and the Philippines. Journal of Forest and Livelihood, 7(1), 19-26.

Dang, T. K. P., Van Der Zouwen, M., \& Arts, B. (2019). Challenges of forest governance: The case of forest rehabilitation in Vietnam. Public Organization Review, 19(4), 425-452.

Davidson, A. P. (2007). Participation, education, and pluralism: towards a new extension ethic. Development in Practice, 17(1), 39-50.

Davis, K. (2008). Extension in sub-Saharan Africa: Overview and assessment of past and current models and future prospects. Journal of International Agricultural and Extension Education, 15(3), 15-28.

Doss, C. R. (2006). Analyzing technology adoption using microstudies: limitations, challenges, and opportunities for improvement. Agricultural economics, 34(3), 207-219.

FAO. (2016). State of the world's forests 2016. Forests and agriculture: Land-use challenges and opportunities. Rome: FAO.

Government of Kenya (GOK). (2011). Draft session paper on devolved government in Kenya: Developmental devolved government for effective and sustainable counties. Government Printers.

Government of Kenya (GOK). (2016). The Forest Conservation and Management Act (2016). Kenya Gazette Supplement No. 155 (Acts No. 34). Nairobi, Kenya: Government Printer.

Kenya Forest Service (KFS). (2015). Implementation of devolved forestry functions (Transition to Devolved Government Act No. 1 of 2012) Transition Implementation Plans 2015 - 2016. Nairobi, Kenya.

KNBS. (2019): Kenya National Population and housing census, Volume 1A. Population distribution by administrative units and subcounties. Kenya National Bureau of Statistics. Ministry of state for planning, National Government and vision 2030. 
Koppmair, S., Kassie, M., \& Qaim, M. (2016). Farm input subsidies and the adoption of natural resource management technologies (No. 333-2016-14585). Selected paper prepared at the 2016 Agricultural \& Applied economics association annual meeting, Boston, Massachusetts, July31-August 2.

Lasco, R.D., Habito, C. M. D., Delfino, R. J. P.,Pulhin, F. B. \& Concepcion, R. N. (2011). Climate change adaptation for smallholder farmers in South Asia. World Agroforestry Centre, Philiphines.65p.

Mbuvi, M. T. E., Ndalilo, L. \& Cheboiwo, J. (2018). Challenges to Actualization of Decentralization Forest Management Functions: Experiences and Lessons on Devolving Forestry Management Functions in Kenya. Public Policy and Administration Research, 8 (10), 84-92.

Mugenda, O., \& Mugenda, A. (2003). Research methods: quantitative \& qualitative approaches. Nairobi, KE: Acts Press.

Mwangi, M., \& Kariuki, S. (2015). Factors determining adoption of new agricultural technology by smallholder farmers in developing countries. Journal of Economics and sustainable development, 6(5).

Okuthe, I. K. (2018). Determinant of the adoption of integrated natural resource management technology by small scale farmers in Ndhiwa division, Kenya. Maseno University.

Oloo, O. M., (2014). Devolving Corruption? Kenya's Transition to Devolution, Experiences and Lessons from the decade of Constituency Development Fund in Kenya. Conference Proceedings of Workshop on Devolution and Local Development in Kenya (pp. 63-74). Nairobi, International Centre for Local Democracy (ICLD).

Rivera, W. \& Alex, G. (Eds). (2004). DemandDriven Approaches to Agriculture Extension: Case Studies of International Initiatives. Agriculture and Rural Development Discussion Paper 10. Washington, DC: The World Bank.
Ruifa, H. U., Zhijian, Y. A. N. G., Kelly, P., \& Huang, J. (2009). Agricultural extension system reform and agent time allocation in China. China Economic Review, 20(2), 303-315.

Sanjay, S. (2017). Women's Roles in Community Forestry Program: A Case of Panchakanya Community Forest User Group of Nuwakot District, Nepal. Masters dissertation. Ritsumeikan Asia Pacific University.

Semana, A. (2004). Agricultural extension at Cross Roads: present dilemma and possible solutions for the future in Uganda. Kampala, Uganda.

Sigdel, B. R., Koirala, S., \& Aryal, P. (2015). Corporate governance in Nepalese financial sector: does policy matter. Lalitpur: Nepal Administrative Staff College

Swanson, B. E. (2006). Extension strategies for poverty alleviation: lessons from China and India. Journal of Agricultural Education and Extension, 12(4), 285-299.

Teresia, M. I. (2014). Analysis of farmers' awareness of agricultural extension devolution and preferences for participatory design of agricultural extension programs in Kenya. Master's Thesis. Nairobi, Kenya: Nairobi University.

KFS. (2015). Implementation of Devolved Forestry Function (2015). Transition to Devolved Government Act No. 1 Of 2012): Transition Implementation Plan (TIPS) For Homabay County Fiscal Year 2015 -2016.

World Bank. (2014). Potential of agroforestry to contribute to poverty alleviation to economic growth and to protection of environmental services in the countries of the Southern and Eastern Africa regions. A discussion Paper. April 2014 